Тетяна Коваленко,

докт. юрид. наук, професор,

професор кафедри земельного та аграрного права

Iнституту права

Київського начіонального університету імені Тараса Шевченка

\title{
РЕЦЕНЗІЯ НА МОНОГРАФІЮ Н. О. БАГАЙ «ТЕОРЕТИЧНІ ПРОБЛЕМИ РОЗВИТКУ АГРАРНОГО ЗАКОНОДАВСТВА УКРАЇНИ ${ }^{1}$
}

Сучасне законодавче регулювання аграрних відносин покликане забезпечити підвищення ефективності сільськогосподарського виробництва та повинне відповідати європейським стандартам, що зумовлює важливість наукового дослідження проблем розвитку аграрного законодавства. Значне оновлення аграрного законодавства призвело до істотної зміни внутрішньої структури цієї законодавчої галузі. Подальші тенденції законодавчого регулювання аграрних відносин в Україні пов'язані також із необхідністю систематизації аграрного законодавства України, розвитком та вдосконаленням окремих законодавчих інститутів, що засвідчує актуальність теми дослідження.

У монографічному дослідженні Н.О. Багай «Теоретичні проблеми розвитку аграрного законодавства України» на основі комплексного аналізу розвитку аграрного законодавства України визначено головні теоретичні засади та напрями вдосконалення вітчизняного аграрного законодавства, розроблено науково-теоретичні засади майбутньої галузевої та інституційної систематизації аграрного законодавства України, обгрунтовано практичні рекомендації щодо вдосконалення розвитку основних законодавчих інститутів, що регулюють аграрні відносини. Слід також підкреслити, що монографія підготовлена в результаті опрацювання значної кількості теоретичних джерел і нормативно-правових актів та глибокої аналітичної роботи автора. Робота характеризується комплексним характером, повнотою і структурованістю викладу, детальним обгрунтуванням власних авторських висновків.

Вибрана автором методологія відповідає рівню сучасних наукових досліджень і поставленим у роботі завданням. Монографія містить аргументоване обгрунтування

${ }^{1}$ Багай Н.О. Теоретичні проблеми розвитку аграрного законодавства України : монографія Івано-Франківськ : Супрун В.П., 2020. 305 с теоретичних засад аграрного законодавства та напрямів його подальшого розвитку включно з рекомендаціями щодо ефективних шляхів його систематизації, спрямованими на вдосконалення законодавчого регулювання аграрних відносин. Це засвідчуе доцільність використання вибраних автором у ході дослідження методів пізнання.

Структура монографії охоплює чотири розділи, що забезпечує послідовний і логічний аналіз основних наукових проблем та вирішення поставлених у роботі завдань. Крім того, монографія містить передмову, у якій подано інформацію про мету роботи, іiї актуальність, наукову новизну і практичне значення, та висновки, якими узагальнено аналіз теоретичних засад законодавчого регулювання аграрних відносин та напрямів вдосконалення аграрного законодавства України. Усі структурні частини монографії логічно пов'язані єдиною метою дослідження.

У першому розділі автор досліджує наукові засади аграрного законодавства та розглядає історичні періоди його розвитку. На основі проведеного дослідження виділено основні напрями наукових досліджень аграрного законодавства у різні періоди його розвитку. Досліджуючи теорію аграрного законодавства України в інтерпретації представників різних наукових поколінь та наукових шкіл, автор сформулювала основні практичні проблеми розвитку аграрного законодавства України на сучасному етапі. Особливої уваги заслуговує аналіз передумов становлення та розвитку аграрного законодавства, а також його генетичного зв'язку з іншими галузями законодавства. На основі аналізу наявних наукових підходів автор запропонувала самостійний авторський підхід до виділення етапів розвитку аграрного законодавства України, за яким пропонується виокремлювати період становлення i розвитку сільськогосподарського законодавства УРСР та період розвитку аграрного законодавства України. 
Другий розділ присвячений дослідженню поняття та ознак аграрного законодавства України, його принципів, а також особливостей структури сучасного аграрного законодавства. У межах цього розділу автором сформульоване теоретичне поняття «аграрне законодавство України», охарактеризовано його основні ознаки, визначено систему принципів аграрного законодавства України та сформульовано пропозиції щодо законодавчого закріплення таких принципів в єдиному нормативно-правовому акті. Крім того, автором визначено особливості сучасної структури аграрного законодавства, охарактеризовано з урахуванням наявних наукових підходів поняття інституту аграрного законодавства. Вартими уваги є міркування вченої щодо характерних ознак сучасного аграрного законодавства України, до яких належать значне розширення структури та змісту аграрного законодавства України, загальна тенденція до поглиблення структурних зв'язків між галузевими утвореннями системи українського законодавства, визнання основною метою аграрного законодавства захист інтересів людини, селянина. Позитивно сприймаються також пропозиції Н.О. Багай щодо необхідності законодавчого закріплення системи міжгалузевих і галузевих принципів аграрного права і законодавства.

У третьому розділі монографії аналізуються особливості розвитку основних інститутів аграрного законодавства. Зокрема, розглянуто особливості законодавчого закріплення державної аграрної політики та державної підтримки сільського господарства України, проаналізовано розвиток законодавства про правове становище суб'єктів аграрних правовідносин (сільськогосподарських кооперативів, колективних сільськогосподарських підприємств, фермерських господарств, державних і комунальних аграрних підприємств тощо), з'ясовано особливості законодавства про виробничо-господарську діяльність в аграрному секторі економіки, досліджено законодавче регулювання трудових відносин у сільському господарстві, проаналізовано законодавство про соціальний розвиток села та правовий статус селянина, досліджено проблеми законодавчого забезпечення охорони довкілля у сільському господарстві та екологізації аграрного законодавства. На основі аналізу розвитку окремих інститутів аграрного законодавства України автором сформульовані важливі пропозиції щодо вдосконалення законодавчого регулювання аграрних відносин. Обгрунтованими видаються судження вченої про важливість законодавчого визначення основних засад державної аграрної політики України на довгострокову перспективу, приведення заходів з державного регулювання аграрного сектору економіки України у відповідність до вимог COT та СС, пропозиції щодо вдосконалення та подальшого розвитку законодавства щодо правового статусу суб'єктів аграрних правовідносин.

У четвертому розділі автор аналізує поняття та основні форми систематизації аграрного законодавства України, а також напрями систематизації основних його інститутів. Автором сформульовано поняття та виділено форми систематизації аграрного законодавства України, проаналізовано основні напрями кодифікації цієї законодавчої галузі, а також висловлено рекомендації 3 приводу майбутньої систематизації окремих законодавчих інститутів, що регулюють аграрні відносини. Виняткової уваги заслуговують пропозиції вченої, що стосуються кодифікації аграрного законодавства шляхом розробки єдиного законодавчого акта, що визначатиме ключові, фундаментальні принципи і напрями регулювання аграрних відносин. Проведений комплексний аналіз питань систематизації аграрного законодавства України дав змогу автору зробити обгрунтований висновок про те, що у сучасний період реформування аграрних відносин доцільно забезпечити кодифікацію аграрного законодавства шляхом розробки єдиного законодавчого акта та узгодити основні нормативно-правові акти інститутів аграрного законодавства з галузевим кодифікаційним актом. Велике значення мають пропозиції автора щодо змісту та форми майбутнього кодифікаційного акта аграрного законодавства.

Монографія характеризується науковою обгрунтованістю та достовірністю висновків, які зроблені з урахуванням наявних наукових підходів та аналізу нормативноправових актів аграрного законодавства. Окремі висновки автора мають дискусійний характер та можуть слугувати основою для подальших наукових досліджень проблем розвитку аграрного законодавства України. Загалом робота Н.О. Багай «Теоретичні проблеми розвитку аграрного законодавства України» має велике теоретичне значення та практичну цінність, тож може бути рекомендована науковцям та здобувачам вищої освіти і водночас може бути використана у разі розробки проєктів нормативно-правових актів та проведення систематизації аграрного законодавства. 